\title{
Can the United States Contain China?
}

Contradictions and Limits of U.S. Power
in the Trump Era and Beyond

Alan W. Cafruny

\begin{abstract}
What factors account for the increasingly erratic U.S. policy towards China, marked by growing domestic divisions and tensions over means and ends? Can the United States contain China, as called for by its military leaders and a growing segment of corporate America? Or, can the Sino-American rivalry be managed peacefully and without plunging the world into depression? The preoccupation with rhetoric and agency in the analysis of U.S. foreign policy overlooks the role of social forces and class interests. The confusion and vacillation in U.S. trade policy are amplified by the manifest dysfunctions of the Trump administration, but they ultimately reflect a deeper, double logic, expressing not only the "Thucydides trap" in which a declining but still formidable hegemon contemplates submission to a rising power but also a crisis of neoliberalism.
\end{abstract}

Keywords: international trade policy, neoliberalism, globalization, U.S. foreign policy, Chinese foreign policy

\author{
Alan W. Cafruny \\ Hamilton College, Clinton, USA \\ Department of Government \\ Henry Platt Bristol Professor of International Affairs, USA \\ ORCID: 0000-0002-7572-9811 \\ E-mail: acafruny@hamilton.edu \\ Address: Clinton, New York 13323, USA \\ This article is an expanded and revised version of the paper written for the Valdai International \\ Discussion Club. The original copy is available at: http://valdaiclub.com/a/valdai-papers/valdai- \\ paper-93-glodal-trade-war-contradictions/
}

DOI: $10.31278 / 1810-6374-2019-17-1-100-122$ 


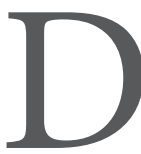

onald Trump campaigned for the presidency as an economic nationalist, promising to "make America great again" by rebalancing international trade in order to bring manufacturing jobs back to the United States. However, immediately after withdrawing from the Transpacific Partnership (TPP), throughout the rest of his first year in office Trump placed the trade agenda on hold, instead pursuing systematically a set of neoliberal policies that promoted a substantial upward redistribution of wealth, spearheaded by a massive reduction in corporate taxes.

Only in his second year in office did Trump turn his attention to international trade by enacting tariffs on steel and aluminum imports from many countries, with the most extensive restrictions applying to China, Russia, and the European Union. The EU and China retaliated with tariffs aimed at U.S. farmers and manufacturing workers. By midyear French Finance Minister Bruno Le Maire declared that "the war has already started," while the Chinese Foreign Ministry proclaimed that the United States had started "the largest trade war" in history.

The EU and the United States declared a truce in July 2018, under which both sides refrained from the imposition of further tariffs pending the outcome of transatlantic negotiations that are expected to resume in 2019. At the G20 conference in Buenos Aires at the end of November 2018, the United States, Mexico, and Canada signed (but have not yet ratified) a renegotiated NAFTA, the U.S.-MexicoCanada Agreement (USMCA). A revised U.S.-South Korea (KORUS) agreement was also signed. The United States and Japan will begin negotiations on a trade deal in 2019.

The outcome of pending U.S.-Japan and transatlantic trade negotiations is uncertain, and much conflict lies ahead even among the G7 allies. However, the U.S.-China rivalry is far more intractable. In October 2018 Trump threatened to raise tariffs from 10\% to 25\% on a $\$ 200$ billion worth of China's exports, pending negotiations, later extending the deadline to March 1, 2019. As global growth slows and global recession looms, leaders have strong incentives to avoid a full-blown trade war. However, underlying structural issues remain and rivalry will persist. What factors are driving U.S. policy towards 
China? Can the Sino-American competition be managed peacefully and without plunging the world into depression?

The dysfunctions and idiosyncrasies within the Trump administration have become increasingly pronounced over time. Not surprisingly there has been an increasing reliance on these factors to explain U.S. foreign policy. Following the July 2018 NATO Summit, European heads of state concluded that "there is little method to the American president's rhetorical madness, and simply no way to anticipate what he might do next" (Herzsenhorn and Baragazzi, 2018). The influential Munich Security Report issued at the beginning of 2019 regrets the departure of the "axis of adults" from the U.S. administration and laments that "U.S. policy is increasingly looking like Trump's tweets" (2019, pp. 12-13). To be sure, the Trump presidency has resulted in an unbroken string of rhetorical excess and erratic implementation, not least with respect to trade policy. Trump's policies and statements are frequently undermined by his own executive branch and key advisors. Intelligence officials publicly contradict him with impunity. Congress has become increasingly active in legislating foreign policy, as exemplified by its ceaseless sanctions, enacted with bipartisan support, now impacting one-third of the world's population. Several bills pending in Congress that seek to reduce executive power over trade and tariffs have also attracted significant bipartisan support.

Yet the preoccupation with rhetoric and "agency" overlooks the role played by social forces and class interests in the making of U.S. foreign policy. American "civil society" remains strong, albeit dominated by the corporate elite which control the basic contours of the policy process (Domhoff, 2017; De Graaf and van Apeldoorn, 2017). Presidents come and go, but the determinant social and class forces and interests remain. Along with institutional and constitutional constraints on the presidency these forces and interests sharply constrain state autonomy. The confusion and vacillation in U.S. trade policy are being amplified by administration dysfunction, but they ultimately reflect a deeper, double logic, expressing not only the "Thucydides trap" in which a declining but still formidable hegemon contemplates submission to a rising power but also a crisis of the neoliberal project. 
The strategic engagement with China was and remains a central factor in the American consolidation of that project. As long as it continues, the significant reduction of U.S. dependence on China will impose massive economic and political costs on any administration. There is no successor project on the horizon.

\section{NEOLIBERAL GLOBALIZATION IN CRISIS}

Although foreign direct investment played an important role in the activities of U.S. banks and multinational corporations throughout the post-World War II period, its significance increased dramatically with the advent of the neoliberal era in the 1980s. The establishment of complex global supply chains enabled U.S. corporations to maintain profitability and market shares as they confronted increasing foreign competition, but also contributed to significant domestic deindustrialization. Whereas in 1953 nearly one-third (32\%) of U.S. employment was in manufacturing, that figure fell to $8.5 \%$ in 2018. Between 1979 and 2010, the United States lost eight million manufacturing jobs. Mobile sections of capital resorted to outsourcing, while less mobile sections increased their reliance on precarious imported migrant labor (Smith, 2016, pp. 46-48).

The North American Free Trade Agreement (NAFTA) and the World Trade Organization (WTO) consolidated this neoliberal strategy. Implemented in 1994 with bipartisan support, the NAFTA further opened Mexican labor markets to U.S. and other Western multinationals. It also created vast new export markets in Mexico for the highly mechanized and subsidized U.S. agricultural sector, even as it drove dispossessed small farmers across the border into the United States and thereby increased the pool of unprotected labor. Automobile production was emblematic of the general trend towards utilizing production chains in the global south, and especially in Mexico. The U.S. auto industry (including German and Japanese firms) imports more than $25 \%$ of its inputs. The engagement with China produced an "epochal shift in patterns of world trade" (Autor, et al., 2016, p. 37), consolidated by its entry into the WTO in 2001, again with bipartisan support. U.S. FDIs in China soared from $\$ 47$ billion in 2001 to $\$ 124$ 
billion in 2011, although since that time it has levelled off as a result of trade tensions and accounts for just $2 \%$ of overall U.S. FDIs. In the eight years prior to becoming U.S. Secretary of the Treasury in 2006, Goldman Sachs CEO Hank Paulson, a leading architect of the opening to China, made 70 trips to Beijing (Landler, 2008).

President Clinton's rhapsody in 1993 on the eve of China's impending accession to the WTO exemplifies the extraordinary hubris and naiveté of corporate America and its neoliberal politicians concerning China and the realities of international relations:

They have to lower tariffs. They open up telecommunications for investment. They allow us to sell cars made in America in China at much lower tariffs. They allow us to put our own distributorships over there. They allow us to put our own parts over there. We don't have to transfer technology or do joint manufacturing in China anymore. This is a hundred to nothing deal for America when it comes to the economic consequences (U.S. Congress, 2010).

By throwing U.S. workers into competition with hundreds of millions of unprotected workers in the global south, outsourcing contributed to wage stagnation as the labor share of GDP in the United States declined and levels of inequality soared. From 1980 to 2018, labor's share of the national income declined from $68 \%$ to $59 \%$, while the share of corporate profits rose from $8 \%$ to $15 \%$. In 1965 , the average U.S. CEO earned 20 times more than the average employee; that ratio had reached 361 by 2018 (Hembree, 2019). Cheaper imports displaced manufacturing jobs but they also crucially served to offset the effect of declining real wages and rising inequality, allowing for a net gain in total worker compensation and thus the maintenance of overall living standards. However, the long-range costs of deindustrialization for the American economy, society, and political culture increased.

The reduction of the U.S. factory workforce-from $15.4 \%$ of the U.S. total in 1992 to $8.5 \%$ in 2018-has transformed the American political and cultural landscape. It triggered an exodus of workers from big cities that were once union citadels into suburbs in which the labor force was atomized, disorganized, and often downwardly mobile (Kuttner, 2018). Representing more than one-third of the private sector 
workforce in 1955, unions now account for less than $7 \%$. As a result of its complicity in the neoliberal policies of the last three decades, the Democratic Party lost much of its base in the U.S. labor movement. After the 1992 election, 15 of the 20 most manufacturing-intensive Congressional districts in the U.S. were represented by Democrats. By 2018 all 20 were held by Republicans (Davis and Chinni, 2018).

The 2016 presidential campaign represented a point of no return. All of the problems afflicting the American working class were exacerbated by the global financial crisis that started in 2007. Coming on the heels of two decades of deindustrialization, the ensuing "great recession" led to further job losses, growing indebtedness, and the loss of homes for millions resulting from the collapse of the housing bubble. Taking office at the height of the crisis, Barack Obama was able to implement a (deeply flawed) national health care plan along with a modest fiscal stimulus. In most other ways, he governed from the perspective of Wall Street, confronted by an increasingly hostile Congress dominated by Tea Party Republicans from 2010 on, and unwilling or unable to take steps to reverse the decline of union membership. In December 1999, 37\% of Republicans agreed that free trade deals helped the U.S., with only $31 \%$ of Republicans disagreeing. By February 2017, the results were vastly different: by $53 \%$ to $27 \%$, Republicans said free trade hurt the United States, and two-thirds of Republicans now support Trump's tariff strategy (Eichengreen, 2018).

\section{POLICY AND PLANNING}

Globalization was "made in (corporate) America", but Trump prevailed in the 2016 elections by framing it in terms of xenophobia, anti-immigrant sentiments, and victimization. In the face of the Democratic Party's abandonment of the working class, Trump promised through his "America First" program to restore jobs and dignity to (white) working class Americans. His performance in midwestern battleground states illustrated the success of this electoral strategy. Notwithstanding his populist rhetoric, Trump assembled the "wealthiest cabinet in modern history," (Gee, 2018) and has governed exclusively on behalf of the key power centers of American capitalism: 
Wall Street, Silicon Valley, oil and gas, and the military industrial complex.

The centerpiece of the new administration's strategy was the Tax Cuts and Jobs Act, passed in December 2017. By greatly reducing corporate taxes, the bill represented a significant advance in the decades-long neoliberal restructuring of American society. As a result of the precipitous unprecedented decline of tax receipts during a time of economic growth, the bill increased the annual budget deficit to $\$ 779$ billion and the total deficit to $\$ 22$ billion (Peterson Foundation, 2018). The transition to a territorial tax system embodied in the Act allows the United States unilaterally to increase the wealth and profitability of American corporations on a global scale at the expense of its competitors, even as much of these profits go to stock buybacks. It leverages the nation's vast market and financial power even as it provides greater incentives for these corporations to invest and produce outside the United States.

A second area of support for big business has been deregulation. With respect to finance, the Dodd-Frank rules enacted in response to the global financial crisis have been significantly relaxed. With respect to environmental policy, the fossil fuel industry has registered massive gains. The Trump administration has also directly targeted labor (Atlantic, 2018). Through appointments to the Supreme Court and as a result of Department of Labor decisions as well as actions by Republican state houses, trade unions have endured a succession of setbacks. The oil and gas sector has also benefited greatly from deregulation, resulting in increased drilling and decreased occupational and environmental safety. Notably, the bid for global energy dominance that has been strongly supported by the Trump administration was started under President Obama, who lifted the 40year ban on crude oil exports (Cohan, 2018). Seeking to increase U.S. LNG exports to Europe the Trump administration has threatened to sanction companies participating in the Nord Stream 2 pipeline project, compelling Europeans to construct two LNG import terminals.

The Trump administration has given unprecedented support to the military industrial complex not only through increases in spending 
but also through assisting weapons exports. In May 2017, Trump requested a study of the Defense Industrial Base under the supervision of Peter Navarro, the nationalist White House Economic Advisor. Undertaken by a dozen working groups across the government and including the Pentagon, the study focuses heavily on the global supply chain and U.S. dependency on Chinese technologies (Mehta, 2018). The administration has also sought to "mobilize the full resources of the U.S. government behind arms transfers that are in the U.S. national and economic security interest" (Spetalnik and Stone, 2018). The "Buy American" initiative launched in May 2018 has relaxed restrictions on weapons exports. Trump has expanded Obama's $\$ 1.2$ trillion upgrade of the U.S. nuclear arsenal. In July, the U.S. Congress, with the support of 139 Democrats, passed a $\$ 716$ billion military budget for 2018 . The projected $\$ 6$ trillion in military spending over the next decade vastly overshadow the $\$ 200$ billion proposed by Trump for infrastructure; indeed, "military Keynesianism" will provide the core of very limited infrastructural development.

\section{FROM NEOLIBERAL CONSOLIDATION TO TRADE WAR}

In the 2016 presidential campaign, the key power centers of American capitalism supported Hillary Clinton as the most reliable steward of neoliberal globalization. However, as noted above, following her defeat, the aforementioned economic policies of the Trump administration and the Republican congressional majority unsurprisingly drew overwhelming support from these same centers. Throughout 2017 and the first two quarters of 2018, corporate profits increased dramatically while equities and business investment surged, driven by tax cuts and deregulation. In the second quarter of 2018, U.S. GDP growth soared to $4.1 \%$ and registered $3 \%$ for 2018 . Although the official unemployment rate has declined, the share of profits and national income going to labor has continued to decrease (Stein, 2018).

However, while the domestic economic policies of upward wealth redistribution united the corporate elite and the Republican Party behind Trump, the threat of trade wars opened up divisions that were largely submerged during 2017. Seeking to protect their investments 
in China, globalists have sought to exert restraint with respect to tariffs towards Europe, to engage Mexico and Canada, and to limit demands on China primarily to obtaining greater access for U.S. banks and financial corporations. The U.S. Chamber of Commerce, the largest business lobby in America, launched a campaign against tariffs. The Koch network, the political arm of Koch Industries and one of the largest and most influential Republican donors, also turned against the Trump administration, at least with respect to trade. Congress has also begun to assert itself more forcefully against tariffs, with pending bipartisan legislation that seeks to limit the president's authority to impose tariffs on national security grounds.

Thus, in practice Trump has been compelled to mediate between the "globalists," represented in his administration by Secretary of the Treasury Steven Mnuchin, a former Goldman Sachs investment banker and hedge fund manager, and the nationalists, led by U.S. Trade Representative Robert Lighthizer and Peter Navarro, Director of the White House Office of Trade and Manufacturing Policy. As Deputy U.S. Trade Representative in the Reagan administration Lighthizer was a key architect of the subjection of then-rising Japan through "voluntary export restraints" and revaluation of the yen. Lighthizer also strongly opposed the admission of China to the WTO, warning that it would become a "dominant" trading nation and that "virtually no manufacturing job in [the United States] will be safe" (Zarolli, 2019).

Like the globalists, the nationalists do not advocate isolationism or a retreat from the global economy. Rather, they believe that multilateral institutions do not allow the United States to fully mobilize its structural economic and political power either to maximize corporate profitability and market shares or to contain China's economic and geopolitical rise. Closely aligned with the Pentagon, they are also concerned about the military implications of a loss of leadership in advanced technologies including artificial intelligence, electric cars, cyber capabilities and, above all, 5G networks. As a result of its "Belt and Road" initiative and its "Made in China 2025" project, which identifies ten industries including 
IT and aerospace for global leadership, China is said to represent a mortal threat to U.S. preeminence (Navarro, 2018).

The nationalists are routinely dismissed by globalists as hotheads and ideologues who fail to understand that the loss of manufacturing jobs is a natural and inevitable process resulting from technological innovation, and that these jobs are being replaced in the service sector. The globalists also contend that trade deficits are primarily the result of budget deficits and a lack of household savings, and not of an overvalued dollar or globalization. There is some truth in these claims and, to be sure, many factors are responsible for trade deficits. However, during the 1990s, the budget deficit was eliminated even as the trade deficit increased dramatically and continued to rise in the early 2000s when the economy suffered demand shortages. The trade deficit itself serves as a "major channel of deindustrialization" (Palley, 2018), as investment is reduced and productivity growth is diminished. Deindustrialization also causes severe socio-political dysfunctions that do not show up in raw unemployment data. Globalists point out that tariffs against China might only achieve a redistribution-and not a reduction-of the overall U.S. trade deficit. However, the nationalists counter that tariffs compel structural concessions from Beijing and encourage U.S. multinationals to disinvest in China.

As China has advanced up the technology scale, concerns about compulsory technology transfers, industrial policies that provide subsidies and financing to domestic firms, and the unfair advantages of state-owned firms have been emphasized by nationalists, but they are also increasingly recognized throughout corporate America. Approximately $90 \%$ of the world's IT hardware, including threequarters of all smartphones, is manufactured in China. China has also made substantial investments in U.S. tech firms, with a focus on artificial intelligence. Even leading officials from the Obama administration have stated that "it might be too late to take decisive actions to prevent Chinese inroads into the tech sector" (Donnan, 2018). There can be little doubt that access to the Chinese market for foreign corporations is predicated on the transfer of technology and intellectual property. However, it is important to emphasize that with these policies China 
is reprising standard, state-led capitalist developmental policies, following a strategy first set out systematically by Alexander Hamilton. In contrast to most developing countries, by virtue of the size of its market and its strong, centralized political system, China has been able to negotiate with multinational corporations on its own terms, an advantage that has not been available to most developing countries.

\section{TRANSATLANTIC RELATIONS:}

\section{DISINTEGRATION OR STRATEGIC DEPTH?}

Although Trump has adopted an aggressive rhetorical posture towards the EU, there is a fundamental distinction between U.S. interests with respect to Europe and North America and those with respect to China. Conflicts within the transatlantic space are more susceptible to resolution on U.S. terms than those with China for two principal reasons. First, in quantitative terms, the transatlantic relationship remains more important to U.S. and European banks and multinational corporations than their relationships with China. Transatlantic economic interdependence is qualitatively deeper than that between the West and China. In 2016 European firms owned $\$ 6.5$ trillion worth of assets in the United States; U.S. firms owned $\$ 3.2$ trillion worth of assets in the EU. The transatlantic space is also characterized by a high level of European economic and geopolitical dependence on the United States. In 2018 the EU registered a record trade surplus with the United States, while exports to China and other trading partners decreased (Eurostat, 2019). Fifty percent of Germany's GDP derives from exports; the United States is Germany's largest export market. BMW's largest global manufacturing facility is in South Carolina, where it produces 500,000 cars annually, half of which are exported, and it is making substantial new investments in the United States and Mexico. European firms exported 1.1 million autos to the United States and manufactured a further 1.8 million.

Second, although the EU, by virtue of its overall GDP, is capable in principle of conducting trade negotiations with the United States as an equal, in practice transatlantic relations are organized on a huband-spoke basis. The euro has divided the EU, accelerating uneven 
development and subordinating much of the continent to a punitive austerity regime under German supervision (Ryner and Cafruny, 2017; Cafruny and Talani, 2019). Moreover, the internal conflicts in the EU are arguably more serious than those between its individual member states and the United States. And, despite torrents of rhetoric and modest nominal steps towards security cooperation, can the EU be considered a military power? While harming the U.S. economy, tariffs would gravely damage the entire European economy that now appears to be slowing and would strike at the heart of the German economy. In 2018 Germany recorded the largest trade surplus (\$299 billion; 7.8\% of GDP) in the world for the third successive year, with a $\$ 49$ billion surplus with the United States (IFO). By contrast, the volume of France's exports to the United States is less than one-third of that of Germany, and its trade balance with the U.S. is roughly equal. France has less to lose from a trade conflict, but Berlin exerts massive power over the Commission's trade policy. In December 2018, German auto industry executives conducted separate discussions on trade in the White House. This asymmetry accounts for the EU's inability to protect its companies from U.S. extraterritorial sanctions (Cafruny and Kirkham, 2019).

The logic of U.S. structural power applies even more directly to its own hemisphere. The USMCA led to modest concessions from Mexico and Canada. The North American regional economy is bound together by complex production chains that also include European and Japanese corporations based in Mexico (especially) and exporting to the United States. Rhetoric aside, Canada and Mexico have no future outside the American embrace and the USMCA. Seventy-five percent of Canada's exports are to the United States, $8 \%$ to the EU, and $5 \%$ to China. The United States accounts for $82 \%$ of Mexico's exports, followed by the EU with $6 \%$ and China with $1 \%$. Notably, the USMCA prevents its signatories from conducting separate negotiations with China.

Structural power similarly affected the tentative agreement made by EU Commission President Juncker and Trump in Washington in July, 2018. The agreement appears to resemble a modest version of 
the frozen Transatlantic Trade and Investment Partnership, aspiring to "zero tariffs" with respect to industrial exports and automobiles, but retaining protections on French agriculture and U.S. public procurement while committing the EU to import more liquefied natural gas (LNG). The United States agreed to refrain from imposing tariffs on automobile exports pending the outcome of negotiations and also called on the EU to support the United States in trade negotiations with China, including by using the WTO to combat intellectual property theft and the operation of state-owned companies.

The return to transatlantic negotiations in 2019 will take place against the backdrop of a Department of Commerce Report issued in February, 2019 that apparently authorizes President Trump to impose $25 \%$ tariffs on EU auto exports. If enacted, these tariffs would deliver a death blow to the German economy. The EU has promised retaliation, even as it refuses U.S. demands to include agriculture in negotiations. At the same time, however, there is widespread U.S. domestic opposition to the tariffs, not least from its own automobile corporations. A full-blown trade war within the transatlantic space is unlikely.

\section{CHINA AND THE UNITED STATES: UNITY AND RIVALRY}

The contradictory actions and rhetoric of the Trump administration towards China reflect not only the depth and complexity of the challenge that it faces, but also the aforementioned divisions and confusion within the U.S. elite as it weighs the short-term costs that would arise from a full-blown trade war against the long-term costs of conciliation. These divisions are notably less salient with respect to the forward military strategy laid out in the Pentagon's National Security Strategy of 2018 that announced a forward strategy of military and industrial containment. It also expands strategic cooperation with Taiwan and India in the "Indo-Pacific" and envisions new military base construction in the East China Sea.

Trade policy towards China has been more inconsistent than the forward military strategy because it reflects the aforementioned divisions and dilemmas within the corporate sector as well as the 
Trump administration but also the continuing centrality of China's labor force and market to the neoliberal strategy. At the outset of his presidency, Trump abandoned Barack Obama's attempt to engage China through multilateral channels in the Trans-Pacific Partnership (TPP) as well as relying on the dispute mechanisms of the WTO. While Obama's "Asian Pivot" and proposed TPP made a start at addressing corporate America's grievances with respect to China-most notably in the area of intellectual property-it did not address a number of key issues, including China's incursions into the U.S. tech sector, as recognized even by Obama administration officials. In March 2018, the United States announced the completion of two investigations into Chinese trade practices. On the basis of these reports, Trump condemned China's "economic aggression" and levied tariffs on steel and aluminum, in violation of WTO rules. In May, China agreed to a number of concessions during high-level talks in Beijing, including measures to decrease the U.S. trade deficit such as increased imports of agricultural goods and LNG and the reduction of tariffs on automobiles and pharmaceuticals. Beijing also accelerated the opening of the financial sector to foreign banks and accepted a punitive decision that fined the Chinese telecoms giant ZTE $\$ 1$ billion for violating sanctions against North Korea and Iran.

Theseconcessions appeared to satisfytheglobalistswhiletemporarily marginalizing the nationalists. During negotiations in Beijing in May, 2018, Secretary of the Treasury Steve Mnuchin reportedly ejected Navarro from the U.S. delegation after a public shouting match; Navarro later compared Mnuchin to Neville Chamberlain (Suebsaeng, 2018). However, the nationalists counterattacked with the Pentagon's decision to exclude China from the autumn 2018 Pacific joint naval exercises and through congressional resistance to the settlement with ZTE, although this was eventually overcome. Trump then escalated the trade war with new measures and threats. In addition to tariffs, through the Committee on Foreign Investment in the United States (CFIUS), the United States has imposed increasingly stringent restrictions on Chinese investments; EU member states have sought to follow the U.S. lead while not burning their bridges with China. China's 
initial response was forceful. Notwithstanding last-minute appeals from Mnuchin, Beijing vetoed the U.S. semiconductor company Qualcomm's bid to take over the Dutch firm NXP Semiconductors, an action that, in Eswar Prasad's words, propelled the United States and China beyond a "mere trade war" to "open economic conflict between the two countries" (quoted in Barfield, 2018).

\section{SINO-AMERICAN CONFLICT AND COOPERATION}

U.S. structural power with respect to China should not be underestimated. Although China's GDP measured in purchasing power parity has already surpasses that of the United States, national accounts data do not accurately indicate underlying power relations (Starrs, 2014, 2018). Notwithstanding the Trump tariffs, China's trade surplus with the United States soared to a record high of $\$ 382$ billion in the first eleven months of 2018. However, U.S. and other foreign firms maintain a massive presence in China, and their supply chains account for a large amount of its exports as well as sales within China. The status of the dollar as an international reserve currency remains unchallenged, and arguably even enhanced in recent years (Goodman, 2019; Economist Intelligence Unit, 2018). In 2018, the renminbi's share of global payments, $1.6 \%$, declined to fifth place, while its share of China's trade fell to $11.5 \%$.

China is experiencing a host of serious problems including massive surplus capacity, mounting debt now at $260 \%$ of (officially declared) GDP and problems in the "Belt and Road" project designed in part to export surplus capacity. China's growth rate has steadily declined. At the end of 2018 the Shanghai Composite was trading at 2014 levels. China also faces adverse demographic trends. The transition to a more domestic, consumption-based growth model has been slow; China's upward redistribution of wealth mirrors that of the United States. China also remains acutely dependent on some Western technologies, especially foreign-made microchips, which accounted for nearly half of its imports by value in 2016 (Leng, 2018). Trump's initial decision effectively to shut down the Chinese telecoms giant ZTE for violating sanctions against Iran, although later rescinded, would have 
been devastating to the Chinese economy, depriving ZTE of access to U.S. firms that supply one-third of its crucial components. These weaknesses provide strong incentives for China to make concessions, but not to abandon its developmental model.

The case of Huawei serves as a microcosm of the U.S.-China rivalry that extends well beyond trade itself and illustrates the dialectics of Sino-American power relations. Declaring that "America will win the global race to 5G," in October 2018 President Trump signed an executive order forbidding government purchases of Huawei products. The Trump administration is considering a complete ban on their imports. In November 2018 on the eve of the G20 Summit, the U.S. Department of Justice indicted Huawei CFO Meng Wanhzou on charges of violation of U.S. sanctions and the theft of trade secrets from T-Mobile, leading to her arrest in Canada and possible extradition to the United States for trial. The extraordinary and highly provocative arrest of Meng by the Canadian authorities was almost certainly a political decision considering the large numbers of companies that have been prosecuted without taking their officers into custody. The threat of extradition and prosecution is thus an important factor in overall trade negotiations.

During the 1980s China turned to the West to develop its technology sector, employing a range of state subsidies and establishing joint ventures and $\mathrm{R}$ and $\mathrm{D}$ programs. Because of the size of its market, it was able to secure the transfer of technology but also limit Western influence even after WTO accession, as exemplified by its exclusion of Facebook and Google. U.S. corporate acquiescence reflected the primacy of short-term profitability over long-term national interest. Between 1999 and 2018 China's share of global high-tech exports increased from $5 \%$ to $25 \%$, although much of the increase was from U.S. companies such as Intel, Apple, and Microsoft. The U.S. share declined from $20 \%$ to $7 \%$ (Goldman, 2019). Emblematic of this transition was Apple, which at the beginning of the 21 st century systematically closed its U.S. factories and constructed Asian supply chains based in China. This strategy provided the labor and resources to develop its iconic iPhone and iPad, but at the same time enabled the rise of 
Huawei, which in 2018 surpassed Apple as the world's largest phone maker. U.S. technological leadership-and its willingness to impose tariffs-are offset by the interconnection of the U.S. and Chinese hightech sectors in production chains throughout Asia. Trump's tariffs harm U.S. firms in China. Twenty-five percent of Apple's net income and 75\% of Qualcomm's are derived from the Chinese market (TingFang and Li, 2019). The seven leading U.S. IT and intercom providers receive the majority of their components from China. As the state-run People's Daily has warned, "the Chinese market is vital for many top U.S. brands...If Apple wants to continue raking in enormous profits from the Chinese markets amid trade tensions, the company needs to do more to share the economic cake with local Chinese people" (Weijia, 2018).

Huawei is now the largest telecommunications company in the world, with a $30 \%$ share of global telecoms sales, including to 45 of the 50 largest wireless carriers (Woo, Strumpf, and Morris, 2018). It is the acknowledged leader in 5G network technology, with its massive commercial but also geopolitical implications. 5G technology is up to 100 times as fast as the existing $4 \mathrm{G}$ networks, with revolutionary implications for commerce and social life as well as warfare and the possibilities for cyber intrusions. Former National Security Advisor and Commander in Chief of U.S. forces in Europe James Jones has compared the company Huawei to the World War II Manhattan Project, stating that Huawei's 5G technology is the 21st century equivalent of the mythological Trojan Horse... with the potential to threaten NATO as the United States will become unable and unwilling to integrate its secure 5G network with any aspect of Chinese systems" (Atlantic Council, 2019). Washington has begun a global campaign against Huawei, pressuring allies to ban its products, thus far with only limited success. The UK and Germany have so far resisted U.S. demands to ban the use of Huawei technologies as they transition to $5 \mathrm{G}$ and effectively establish a bifurcated global telecoms industry (Purnell, Roy, and Volz, 2019; Soo, 2019). The United States has not provided proof that Huawei has engaged in illegal commercial theft of technologies or that it has the technical capacity to breach cybersecurity 
systems. Robert Hannigan, former head of GCHQ, the UK signals intelligence agency, recently wrote in the FT that NCSC had "never found evidence of malicious Chinese state cyber activity through Huawei" and that any "assertions that any Chinese technology in any part of a $5 \mathrm{G}$ network represents an unacceptable risk are nonsense" (Sevastopolo and Bond, 2019). At the same time, however, EU officials have reportedly rejected proposals from senior Chinese officials for a "Grand Alliance" against the United States under which China would grant the EU preferential access and China and the EU would launch a joint offensive in the WTO (Emmot and Barkin, 2018). The United States has also launched a campaign to restrict Chinese activities in Eastern Europe (Atlantic Council). While the results of the campaign have been limited, the coercive power deriving from the United States' ability to impose sanctions on both allies and "strategic competitors" through the long arm of the Departments of the Treasury and Justice cannot be underestimated (Cafruny and Kirkham, 2019).

This new stage of global disarray contrasts ominously with previous post-World War II international economic crises. The severe economic turbulence of the 1970s and the 1980s that resulted in the United States' unilateral exit from the dollar/gold standard gave rise to the G7 (and, for a time, the G8), followed eventually by a multilateral accord on the revaluation of the DM and the yen. Contrary to the romanticized narrative of pre-Trumpian pristine liberal internationalism, these actions were unilateral and highly coercive. However, although they served to reassert its hegemony over Western Europe and Japan, the United States did not repudiate the principle of multilateral cooperation as an end goal.

The global financial crisis that started in 2007 also resulted in significant multilateral cooperation, including the formation of the G20, the collective renunciation of protectionism, and U.S. and Chinese fiscal stimulus as the United States Federal Reserve, acting in "enlightened self-interest ...made itself into a lender of last resort for the rest of the world"(Tooze, 2018, p. 202). However, the contemporary 
global disarray is qualitatively different. For the first time since World War II, the United States is confronting an economic challenger not from within its own imperium, but rather from a geopolitical competitor, and from a far weaker position. Thus the U.S.-China conflict is in many respects more dangerous than the Cold War. Soviet foreign policy was not driven by a relentless, expansionary economic logic, as is the case with both China and the United States (but not Russia) today. A U.S. strategy of maximum containment, even with its G7 allies on its side, is certain to provoke global chaos, but unlikely to derail China's rise over the long term.

Offering no tangible benefits to his working class supporters, Trump cannot lightly abandon a confrontational trade posture that serves as symbolic compensation for neoliberal policies. Yet, as the 2020 election approaches, Trump also recognizes the cost of trade conflicts, not only for important sectors of the U.S. economy but also the stock market, which he sees as a barometer for the U.S. economy in general. Tariffs have imposed substantial costs on American farmers and auto workers, and have produced very few new jobs, even in the steel industry (Bureau of Labor Statistics, 2019). These considerations suggest the possibility of a U.S.-China agreement, centered on a reduction of China's trade surplus and liberalization of inward foreign direct investment. Yet, even if such an agreement can be made and result in acceptable enforcement mechanisms, it will not extend to the underlying structural issues that ultimately lie at the heart of SinoAmerican rivalry.

Corporate America will not easily relinquish its increasingly tenuous primacy within the Asian market that is projected to account for more than $50 \%$ of global GDP by 2050 . Ironically, it appears to be moving gradually towards the more hawkish position already staked out by nationalists in the USTR, the Pentagon, and both parties in Congress, and at least partially relinquished by Trump. In their January 2019 Report to the USTR, the U.S. Chamber of Commerce and the American Chamber of Commerce in China protested the "deep, concerted, and continuing effort" by Chinese officials to pursue the Made in China 2015 plan (Davis and Wei, 2019). Even more 
emblematic is the conversion of Hank Paulson to a far more hawkish position: "The attitude that [China] would implement reforms at a timetable that made sense to them missed the fact that this was no longer sustainable if they wanted the United States to keep its markets open to them. And the U.S. business community now supports a harder line" (Sevastopulo, 2019). This harder line appears to rely on a long-term strategy of decoupling and bifurcation. Many U.S. firms are in fact gradually shifting their supply chains out of China to other Asian countries (Ip, 2018; Kawase, 2019; Friedlander, 2019). Yet, such a strategy would require many years; the size of the Chinese market and the reluctance of allies to follow the American lead almost certainly precludes wholesale decoupling.

More fundamentally, the nationalist strategy is in many respects incoherent if pursued in the context of neoliberalism. Even if China's high-tech offensive could be contained through a strategy of decoupling, it would not necessarily lead to significant de-globalization or benefit most Americans through the restoration of manufacturing. To the extent that corporations are rerouting supply chains out of China, the jobs and manufacturing are not returning to the United States but relocating elsewhere in Asia (see, for example, Kawase, 2019). While this process might augment the power and interests of corporate America, its impact on U.S. society would be very limited. Connected to a project of neoliberal consolidation, the strategy does not allow for a genuine (re)industrial strategy; redistribution of wealth and income; or adequate funding for infrastructure, research and development, and general education. The social forces within American society that could bring about these policies-the basis of a long-range, multilateral settlement that could bring mutual benefits to the Chinese and American people-are gathering force but are still very weak and disorganized.

\section{References}

Atlantic Council, 2019. General James Jones. Recommendations on 5G and national security. Brent Scowcroft Center for Strategy and Security, 11 February. Washington, D.C. 
Autor, D. and Hanson, G., 2016. The China shock: learning from labor market adjustment to large changes in trade. NBER, International Trade and Investment, Labor Studies, Working Paper No. 21906, January.

Barfield, C., 2018. China knifed qualcomm: now the U.S. should pull the plug on ZTE. American Enterprise Institute, Washington, D.C. 26 July.

Cafruny, A. and Talani, L.S., 2019. German ordo-liberalism and the future of the European Union. Critical Sociology, forthcoming.

Cafruny, A. and Kirkham, K., 2019. A sovereign Europe? EU 'autonomy' in global governance: the case of sanctions. In: Grigoriev, L. and Pabst, A. Global governance in transition: challenges for international cooperation. New York: Springer, forthcoming.

Cohan, S., 2018. Trump's energy dominance and the future of fossil fuels. Earth Institute, 9 February. New York: Columbia University.

Davis, B. and Chinni, D., 2018. America's factory towns, once solidly blue, are now a GOP haven. Wall Street Journal, 19 July.

Davis, B., and Wei, L. 2019. China's plan for tech dominance is advancing business groups say. Wall Street Journal, 22 January.

Domhoff, W., 2017. The power elite and the state. London: Routledge.

Donnan, S., 2018. The AI arms race: the tech fear behind Donald Trump's trade war with China. Financial Times, 5 July.

De Graff, N. and van Apeldoorn, B., 2018. U.S.-China relations and the liberal world order: contending elites, colliding visions. International Affairs, 94(1).

Economist Intelligence Unit, 2018. Renminbi internationalism and the BRI: rebuilding momentum?" 10 April.

Eichengreen B., 2018. Can a trade war be averted? Project Syndicate, 10 April.

Emmot, R. and Barkin, N., 2018. Exclusive: China presses Europe for anti-U.S. alliance in trade. Reuters Business News, 3 July.

Friedlander, J., 2018. How the arrest of Meng Wanzhou may mark the start of the great China-U.S. technology decoupling. South China Morning Post, 27 December.

Gee, T. 2018. The gold-plated Cabinet. Politico, March-April.

Goldman, D., 2019. How to meet the challenge posed by China. Imprimis, 12 February. Hillsdale, Michigan. 
Goodman, P. 2019. The dollar is still king: how did that happen? New York Times, 23 February.

Henbree, D. 2018. CEO pay skyrockets to 361 times that of average worker. Forbes, 21 May.

Herzshenhorn, D. and Baragazzi, J, 2018. Very stable Trump: European leaders beg to differ. The Atlantic, 7 July.

Ip, G. 2018. Trump didn't kill the global trade system: he split it into two. Wall Street Journal, 26 December.

Kawase, K. 2018. How Asian companies are navigating the trade war. Nikkei Asian Review, 19 September.

Kuttner, R., 2018. Can democracy survive global capitalism? New York: W.W. Norton.

Leng, S., 2018. China must stop fooling itself it is a world leader in science and technology. South China Morning Post, 27 June.

Mehta, A., 2018. Trump's industrial base review coming in May. Defense News, 25 April.

Munich Security Report, 2019. The great puzzle: who will pick up the pieces. Munich: Munich Security Conference.

Navarro, P., 2018. Trump's tariffs are a defense against China's aggression. Wall Street Journal, 20 June.

Palley, T., 2018. Globalization checkmated? Political and geopolitical contradictions coming home to roost. Political Economy Research Institute, Working Paper Series, No. 466, July. University of Massachusetts Amherst.

Peter G. Peterson Foundation, 2018. Corporate tax receipts took and unprecedented drop this year. Washington: Peterson Foundation, 17 October.

Purnell, N., Roy, R. and Volz, D., 2019. U.S. campaign against Huawei runs aground. Wall Street Journal, 22 February.

Ryner, M. and Cafruny, A., 2017. The European Union and global capitalism: origins, development, crisis. London: Palgrave MacMillan.

Sevastopulo, D. and Bond, D., 2019. UK says Huawei is manageable risk to 5G. Financial Times, 17 February.

Sevastopulo, D., 2019. Why Trump's America is rethinking engagement with China. Financial Times, 14 January.

Smith, J. 2016. Imperialism in the 21st century. New York: Monthly Review. 
Soo, Z. 2019. U.S. indictments against Huawei a step towards splitting the world's telecoms industry in two. South China Morning Post, 29 January.

Spetalnick, M. and Stone, M., 2018. Arming the world: inside Trump's buy American drive to expand weapons exports. Reuters, 17 April.

Starrs, S., 2014. America's economic power has not declined-it globalized: summoning the data and taking globalization seriously. International Studies Quarterly, 57(4).

Stein, J., 2018. Federal Reserve Chair: decline in worker share of national economy very troubling. Washington Post, 17 July.

Starrs, Sean Kenji 2018. Can China unmake the American making of global capitalism?" In: Panitch, L. and Albo, G. (eds). A world turned upside down? London: The Merlin Press.

Suebsaeng, A., 2018. Trump Advisor Peter Navarro slams Mnuchin as Neville Chamberlain. Daily Beast, 24 May.

Ting-Fang, C. and Li, L., 2019. Apple held hostage by its Chinese puzzle. Nikkei Asian Review, 1 February.

Tooze, A., 2018. Crashed: how a decade of financial crises changed the world. New York: Viking.

U.S. Congress, 2010. Evaluating China's role in the WTO over the past decade. Testimony of Robert Lighthizer before the U.S.-China Economic and Security Review Commission. 9 June. Washington, D.C.

Weijia, H., 2018. Strong sales of U.S. brands, including Apple, give China bargaining chips in trade row. Peoples Daily, 7 August.

Zarolli, J. 2018. Expect change: Robert Lighthizer is Trump's hardball playing China trade negotiator. NPR, 21 February.

Woo, S., Strumpf, D. and Morris, B., 2018. Huawei seen as possible spy threat. Wall Street Journal, 8 January. 